\title{
Consumer Expectations on Supermarkets in Organized Retailing
}

\author{
DE. VIJAYA DEEPIKA ${ }^{1}$, N. KANNAN ${ }^{2}$ \\ ${ }^{1}$ Assistant Professor, School of Management, D.G. VAISHNAV COLLEGE, CHENNAI \\ 1,2 Research Scholar, SATHYABAMA INSTITUTE OF SCIENCE AND TECHNOLOGY (DEEMED TO BE UNIVERSITY), \\ ${ }^{2}$ Research Supervisor, SATHYABAMA INSTITUTE OF SCIENCE AND TECHNOLOGY (DEEMED TO BE UNIVERSITY) \\ CHENNAI. E-mail: ${ }^{1}$ vijayadeepika@gmail.com, ${ }^{2}$ kannu74@gmail.com
}

\begin{abstract}
The study emphasise on the consumer expectations on supermarkets in organised retailing and factors which acts as driving force for consumers to opt for the same, with reference to Chennai city. The sample size is 120 respondents who were retail customers of Supermarkets under Non- Probability Judgment Sampling method. The growth of Supermarkets of India in recent years has been witnessed due to increased consumer expectations. As most of the retail segments try to find their way to come out of the COVID-19 pandemic, it must be noticed that the consumers are already evolving at great speed in their expectations in all fields. At the pandemic situations, people try to venture out most importantly for essential items with the available outlets, taking care of all safety measures. The immediate next option available for consumers is online shopping. The blowout of virus has not only changed the way how consumers shop, but also their buyer behaviour pattern and what they actually expect from retailers. By 2025, India is expected to become the world's third largest economy as it is experiencing the world's fastest growing economies. According to various reports, it is known that these new spending and shopping patterns is expected to continue even after the crisis comes down. With more developments as well as challenges in the field of organized retailing, consumer preferences are changing from region to region.
\end{abstract}

Keywords: Organized Retailing; Supermarkets; Consumer Expectations

JEL Classification: C1, L2

Received: June 02, 2021

Accepted: September 13, 2021 


\title{
Expectativas de los Consumidores sobre los Supermercados en el Comercio Minorista Organizado
}

\author{
DE. VIJAYA DEEPIKA ${ }^{1}$, N. KANNAN ${ }^{2}$ \\ ${ }^{1}$ Assistant Professor, School of Management, D.G. VAISHNAV COLLEGE, CHENNAI \\ 1,2 Research Scholar, SATHYABAMA INSTITUTE OF SCIENCE AND TECHNOLOGY (DEEMED TO BE UNIVERSITY), \\ ${ }^{2}$ Research Supervisor, SATHYABAMA INSTITUTE OF SCIENCE AND TECHNOLOGY (DEEMED TO BE UNIVERSITY) \\ CHENNAI. E-mail: ${ }^{1}$ vijayadeepika@gmail.com, ${ }^{2}$ kannu74@gmail.com
}

\begin{abstract}
RESUMEN
El estudio hace hincapié en las expectativas de los consumidores sobre los supermercados en el comercio minorista organizado y los factores que actúan como fuerza motriz para que los consumidores opten por los mismos, con referencia a la ciudad de Chennai. El tamaño de la muestra es de 120 encuestados que eran clientes minoristas de supermercados con el método de muestreo de juicio no probabilístico. El crecimiento de los supermercados de la India en los últimos años se debe a las mayores expectativas de los consumidores. Mientras la mayoría de los segmentos minoristas tratan de encontrar su camino para salir de la pandemia COVID-19, hay que notar que los consumidores ya están evolucionando a gran velocidad en sus expectativas en todos los campos. En las situaciones de pandemia, la gente intenta aventurarse sobre todo en busca de artículos de primera necesidad en los puntos de venta disponibles, cuidando todas las medidas de seguridad. La siguiente opción inmediata que tienen los consumidores es la compra online. El estallido del virus no sólo ha cambiado la forma de comprar de los consumidores, sino también su patrón de comportamiento de compra y lo que realmente esperan de los minoristas. Para 2025, se espera que India se convierta en la tercera economía del mundo, ya que está experimentando las economías de más rápido crecimiento del mundo. Según varios informes, se sabe que se espera que estos nuevos patrones de gasto y de compra continúen incluso después de la crisis. Con más desarrollos así como desafíos en el campo de la venta minorista organizada, las preferencias de los consumidores están cambiando de una región a otra.
\end{abstract}

Palabras clave: Comercio minorista organizado; Supermercados; Expectativas de los consumidores

Clasificación JEL: C1, L2 


\section{Introduction}

The Pandemic has created great impact on consumers right from the beginning. The shift in customer preferences was witnessed in all sectors. The physical stores were shirked overnight with most of them being shut down on immediate basis. Customers demand on essential goods made retail segment to think more potentially. Priority was given to health and supply chain safety over price and convenience. The Indian supermarkets mainly focus with retail food items, groceries and household goods. With increasing expectation and modernization in retail, Supermarkets are set up all over India, specifically in big-urban areas with wide coverage. The growth of the Indian supermarkets is mainly due to the rise in the Indian service sector. Our country has made significant reforms over the past years to encourage greater domestic consumption and investment. The current requirements on food and grocery shopping is also witnessing great change with stores have stepped up to make item availability, health, and safety a priority for customers. With new information being released every day, there are changes in the minds of consumers with regards to buying behaviour at Supermarkets.

\section{Review of literature}

P.F. Venter and M. Dhurup (Dhurup, 2005) The study proved that consumers give more importance to the physical aspects variable and overall attributes offered by the retailer. In order for the supermarkets to establish or enhance service quality, they have to confirm that working staff members at supermarkets are polite and courteous to customers. They must also have knowledge on products as well to handle customers promptly. Rama Venkatachalam and Arwah Madan (Madan, 2012) have highlighted on price of goods, variety and newness of groceries \& availability of exotic ranges, physical display arrangements $\&$ cleanliness, delivery options \& payment facility provided by retailers in both organized and unorganized. The focus was also on the change in customer preference which has been noticed while shopping fresh grocery from unorganized or organized retailers. The author has emphasised that organized retailing is taking more initiatives in delivering right aspects to sustain, survive and grow in the Retail Industry. According to PWC report (report, 2012) the driving forces for Indian retail industry are, higher incomes driving the purchase of essential and non-essential products, evolving consumption patterns of Indian customers. There are many factors driving this growth in the organised retail market in India, the primary among them being healthy economic growth, changing demographic profile, increasing disposable incomes, urbanisation, changing consumer tastes and preferences. According to Dr. Seema S. Shenoy, Dr. Sequeira and Dr. Devaraj, K. (Dr. Seema S. Shenoy, 2013) Global retailers have great investment and business options in India. The role and development of Indian retailing has been was discussed in the study which concluded that organized retailing are growing in a fast pace. The important factors driving the growth in the organised retail market in India were healthy economic growth, shift in demographic profile, increasing personal disposable incomes, modernisation, trends in consumer tastes and preferences. From a simple activity of selling in small markets to a more sophisticated task of bidding on-line, retailing has showcased several successful forms and facets. K. Venkateswara Raju and D. Prasanna Kumar (Kumar) (2016) Out of various findings the authors insisted on the role of merchandise in organized retailing, it was found that the visual merchandising makes the products appear appealing to the consumer's needs and the Space factor was found to be the important consideration in consumer shopping.

\section{Research design}

The major goal of this study is to determine the consumer expectations on supermarkets in organised retailing and factors which acts as driving force for consumers to prefer the supermarkets. 


\section{Scope of the study:}

This study is confined to selected areas in Chennai City to users of supermarkets covering different age groups. Most of the consumers have covered few major supermarkets in city. As the country stays in door essentially to break the chain of COVID-19, there are several basic categories of services, which are serving people with dedication. Grocery falls under one such category and supermarkets are showing their presence during such tough and challenging times.

\section{Objectives of the study:}

To determine the consumer expectations in Supermarkets and to analyse the parameters that drive the customers to choose Supermarkets during the pandemic.

\section{Hypothesis:}

$\mathrm{H}_{0}$ : There is no significant difference in consumer expectations on supermarkets and their preference of supermarkets.

$\mathrm{H}_{\mathrm{a}}$ : There is significant difference in consumer expectations on supermarkets and their preference of supermarkets.

\section{Research methodology:}

This research aims to identify role of Supermarkets in organized retailing in Chennai city. The sample size is 120 respondents who were retail customers of Supermarkets under Non- Probability Judgment Sampling method. Pre testing of Questionnaire was done before the survey with 22 respondents. In order to determine the reliability of the scales in the questionnaire, the Cronbach's alpha reliability test was applied using SPSS. The value was indicated as 0.798 which proved acceptable consistency of the scales of the questionnaire. The respondents were all people who are customers of various supermarkets within Chennai city.

\begin{tabular}{|c|c|c|}
\hline \multicolumn{3}{|c|}{ Reliability Statistics } \\
\hline Cronbach's Alpha & $\begin{array}{c}\text { Cronbach's Alpha Based on } \\
\text { Standardized Items }\end{array}$ & N of Items \\
\hline .798 & .795 & 13 \\
\hline
\end{tabular}

A thirteen-question questionnaire was devised to measure the consumer expectations on supermarkets in organized retailing. Each question was a 5-point Likert item from "strongly disagree"

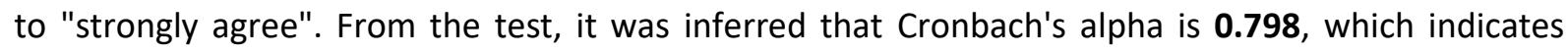
acceptable level of internal consistency for the scale with the specific sample.

\section{Limitations}

The sample was limited to a particular geographical range due to pandemic. Data collected in other areas may produce different results. The response was given by the respondents based on their buying experiences and expectations on particular supermarket outlets thus making the research restricted to few supermarkets. However, the qualitative research methods may bring different results.

\section{Analysis and discussion}

Online Survey method was used for collecting data for the research purpose. A structured questionnaire along with Likert's scale was employed for the study. The collected data were coded in an IBM SPSS Statistics 25.0 version spreadsheet to perform simple statistical analysis such as chisquare test and descriptive statistics. 
Table 1: General Profile of Respondents

\begin{tabular}{|l|c|c|}
\hline \multirow{2}{*}{ DEMOGRAPHIC FACTORS } & $\begin{array}{c}\text { RESPONDENTS } \\
\text { CHARACTERISTICS }\end{array}$ & $\begin{array}{c}\text { RESPONDENTS } \\
\text { (IN PERCENTAGE) }\end{array}$ \\
\hline \multirow{3}{*}{ GENDER } & MALE & 48 \\
\hline \multirow{3}{*}{ MONTHLY INCOME } & FEMALE & 52 \\
\cline { 2 - 3 } & LESS THAN Rs. 20,000 & 12 \\
\cline { 2 - 3 } & Rs. 21,000-Rs. 40,000 & 32 \\
\cline { 2 - 3 } & Rs. 41,000- Rs.50,000 & 26 \\
\hline \multirow{2}{*}{ MARITAL STATUS } & ABOVE Rs. 50,000 & 30 \\
\hline \multirow{3}{*}{ OCCUPATION } & SINGLE & 41 \\
\cline { 2 - 3 } & MARRIED & 59 \\
\cline { 2 - 3 } & SALARIED & 54 \\
\cline { 2 - 3 } & SELF-EMPLOYED & 36 \\
\hline \multirow{2}{*}{ Source: Primary Data } & UNEMPLOYED & 10 \\
\hline
\end{tabular}

INTERPRETATION: From the above table, we can infer that out of 120 respondents, $48 \%$ are male and $52 \%$ are female. On further classification according to their marital status which indicates that $41 \%$ of respondents are unmarried, while $59 \%$ belong to married category. On the basis of monthly income $12 \%$ earn less than Rs.20,000, 32\% earn between Rs.21,000 and Rs.40,000, 26\% earn between Rs, 41,000 and Rs.50,000 and finally 30\% earn more than Rs.50,000. On terms of Occupation, $54 \%$ are in salaried group, $36 \%$ are self-employed and $10 \%$ are unemployed.

Table 2: Consumer Expectation Parameters on Supermarkets

\begin{tabular}{|l|c|c|}
\hline PARAMETERS ON PREFERENCE OF SUPERMARKETS & $\mathrm{N}$ & Mean Values \\
\hline PREFERENCE OF SUPER MARKETS & 120 & 3.42 \\
\hline SAFETY PRECAUTIONS ON PANDEMIC & 120 & 4.09 \\
\hline DOOR DELIVERY & 120 & 3.34 \\
\hline VARIETY OF GOODS & 120 & 3.96 \\
\hline EASY SHOPPING EXPERIENCE & 120 & 4.23 \\
\hline PERSONAL ATTENTION & 120 & 3.42 \\
\hline PHYSICAL ARRANGEMENT OF ITEMS & 120 & 4.27 \\
\hline EXCHANGE POLICY & 120 & 3.36 \\
\hline BILLING \& PAYMENT OPTIONS & 120 & 3.88 \\
\hline FRIENDLY EMPLOYEES & 120 & 3.68 \\
\hline QUALITY OF PRODUCTS & 120 & 3.94 \\
\hline LOCATION OF SUPER MARKETS & 120 & 4.22 \\
\hline AVAILABILITY OF HANDSANITIZERS & 120 & 3.94 \\
\hline
\end{tabular}

Source: Primary Data

INTERPRETATION: The above analysis indicates that in this research various factors like shopping preferences, Safety precautions during Pandemic, exchange policies of supermarkets, the billing options available, Physical arrangements of goods, the quality of product ranges and location of the supermarkets were considered to identify the factors which drive consumers to opt for supermarkets. Significantly the factors were averaged to find out it's impact on grocery purchases. Among all the parameters, Physical arrangement of products in supermarkets had the highest impact on 4.27 Mean which shows consumer's expectations and preference in supermarket purchasing over ordinary grocery stores. 
Table 3: Relationship Between Consumers Expectations on Supermarkets and Choice of Supermarkets

\begin{tabular}{|c|c|c|c|c|c|c|}
\hline \multicolumn{7}{|c|}{ CONSUMERS EXPECTATIONS ON SUPERMARKETS AND CHOICE OF SUPERMARKETS } \\
\hline \multirow[b]{2}{*}{ CONSUMER EXPECTATIONS } & \multicolumn{5}{|c|}{ CHOICE OF SUPERMARKETS } & \multirow[b]{2}{*}{ Total } \\
\hline & Nilgiri's & $\begin{array}{c}\text { Grace } \\
\text { Super } \\
\text { Market }\end{array}$ & $\begin{array}{c}\text { Reliance } \\
\text { Fresh }\end{array}$ & $\begin{array}{c}\text { Spencer's } \\
\text { Daily }\end{array}$ & Others & \\
\hline Convenience of Shopping & 5 & 12 & 2 & 3 & 3 & 27 \\
\hline Packing & 3 & 14 & 15 & 4 & 2 & 41 \\
\hline Quality Of Products & 1 & 8 & 8 & 4 & 1 & 22 \\
\hline Billing \& Payments Options & 5 & 7 & 5 & 2 & 1 & 19 \\
\hline Variety Of Products & 3 & 4 & 5 & 2 & 1 & 11 \\
\hline Total & 17 & 45 & 35 & 15 & 8 & 120 \\
\hline
\end{tabular}

Source: Primary Data

\section{CHI-SQUARE TEST:}

\begin{tabular}{|l|c|c|c|}
\hline \multicolumn{2}{|c|}{ Chi-Square Tests } & $\begin{array}{c}\text { Asymptotic } \\
\text { Significance (2- } \\
\text { sided) }\end{array}$ \\
\hline Pearson Chi-Square & Value & df & .039 \\
\hline Likelihood Ratio & $27.218^{\mathrm{a}}$ & 16 & .005 \\
\hline Linear-by-Linear Association & 34.027 & 16 & .284 \\
\hline N of Valid Cases & 1.150 & 1 & \\
\hline
\end{tabular}

HYPOTHESIS 1: There is no significant relationship between Consumer's expectations on supermarkets and their choice of Supermarkets.

INTERPRETATION: As per the Chi-square Tests, the relationship between Consumer's expectations on supermarkets and choice of supermarkets are tested. The Pearson's Chi-square value is 27.218 and significant value stands at 0.039 which is less than 0.05 . Thus we can infer that there is relationship between Consumer's expectations on supermarkets and choice of Supermarkets.

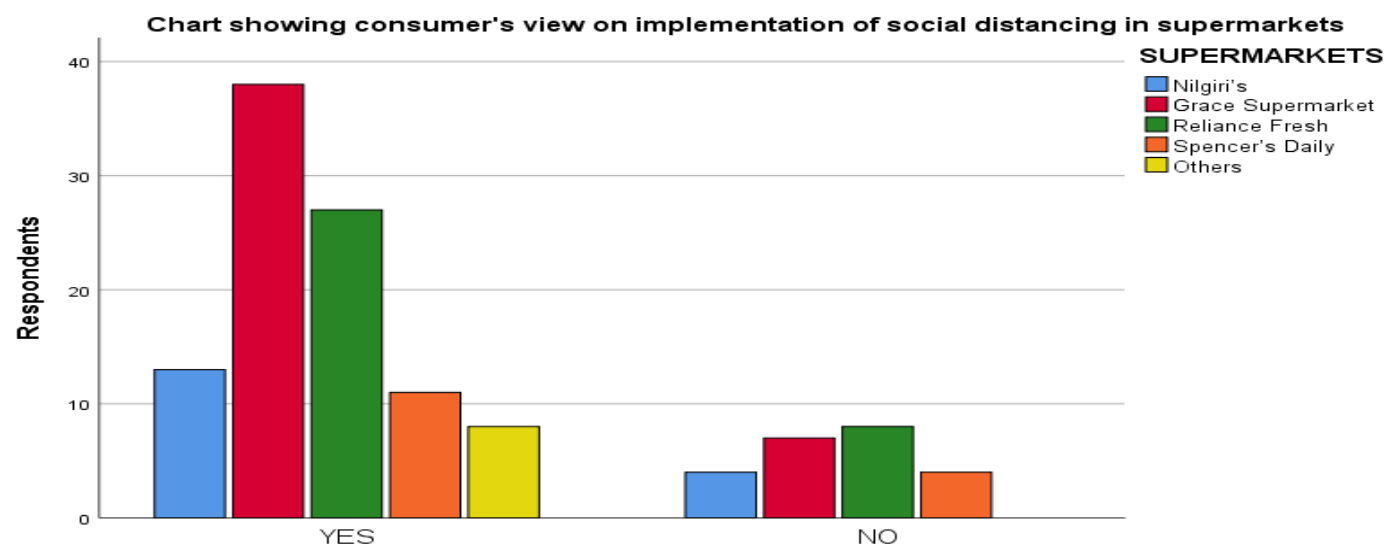

IMPLEMENTING SOCIAL DISTANCING OPTIONS

Source: Primary Data 
Table 4 : T - Test For Significant Difference Between Gender Preferences With Respect To Product Range Of Purchase At Supermarkets

\begin{tabular}{|c|c|c|c|c|c|c|}
\hline \multirow{3}{*}{$\begin{array}{l}\text { PRODUT RANGE OF } \\
\text { PURCHASE AT } \\
\text { SUPERMARKET }\end{array}$} & \multicolumn{4}{|c|}{ GENDER } & \multirow{3}{*}{$\mathrm{t}$ value } & \multirow{3}{*}{$P$ value } \\
\hline & \multicolumn{2}{|c|}{ MALE } & \multicolumn{2}{|c|}{ FEMALE } & & \\
\hline & Mean & SD & Mean & SD & & \\
\hline Groceries & 2.72 & .933 & 3.18 & .897 & 2.710 & .008 \\
\hline House Hold Essentials & 2.36 & .613 & 2.63 & .873 & 1.949 & .054 \\
\hline Stationery & 2.33 & .758 & 2.85 & .989 & 3.289 & .001 \\
\hline Package Food Products & 2.62 & .813 & 2.94 & 1.158 & 1.733 & .086 \\
\hline Personal Care Products & 1.90 & .718 & 2.00 & .868 & 0.713 & .477 \\
\hline
\end{tabular}

Source: Primary Data

HYPOTHESIS 2: There is no significant relationship between Male and Female preferences on product range of purchase at Supermarkets.

INTERPRETATION: The $\mathrm{P}$ value is less than .05 with .001 , which shows there is significant relationship between the male and female choice and preferences in purchasing stationery at supermarkets, thus by rejecting the null hypothesis. With $\mathrm{P}$ value of .008 which is lesser than .05 , we can infer that there is significant relationship between male and female preferences with choice of grocery purchase, thus by rejecting the null hypothesis. The other P values of .054, .086 and .477 which is greater than .05 indicates that there is no significant relationship between male and female preferences of product purchase at house hold products, packaged food products and personal care products, thus by accepting the null hypothesis.

\section{Findings}

The study helped to find the role played by supermarkets in day to day life of general public, their choice of preferences on grocery shopping along with few major attributes which makes supermarkets to be in daily part of their life. COVID-19, the game changer for various sectors had its impact on grocery market which has a major influence on the Supermarkets. The Indian grocery business is unique in many ways, primarily due to the diversity and choice of consumers and the distinctive availability of supermarkets in the retail sector. This makes the reach of supermarkets to be high in spite of availability of mom and pop stores to online grocery stores and other the grocery business channels. Thus the understanding of consumer requirements by the supermarket sector can contribute to more business opportunities and higher expansion too. Especially during the pandemic, many supermarkets worked extensively considering the safety of the consumers at the same time serving their needs by taking into account the restrictions and norms which were prescribed the the Government.

\section{Conclusion}

Supermarkets have great impact on the consumer buying behaviours in organized retail sector. The retailers of supermarkets must understand the needs of consumers and take necessary measures to meet their expectations. With increased challenges being faced by organized retail industry specifically by supermarkets, the retailers must always be on line with the requirements of the consumers. According to recent reports, Indian Grocery market accounts to $69 \%$ of India's total retail market, which thus offers plenty of opportunities to substantial retailers. There has been a substantial difference in the way people have changed their shopping behaviour in supermarkets since the start of pandemic. Thus supermarkets have implemented new regulations according to 
Government guidelines to fight the virus with social distancing as a factor which the customers have to adhere strictly.

\section{References}

1. Venkateswara Raju. K, Prasanna Kumar. D (2016) A study of the organized retail scenario in India and Customer Impulsiveness in Organized Retail Outlets, ISSN: 0971-1023, NMIMS Management Review, Volume XXXII November 2016.

2. Venter P.F and Dhurup. M (2005) Consumer perceptions of supermarkets Service Quality: Scale development and validation, SAJEMS NS 8 (2005) No 4.

3. Shailesh Pandey and Dr. Vipin Chand Rai (2014), International Journal of Engineering and Management Research, Consumer Behavior towards Retail Outlets in India - Literature Review, Volume-4, Issue-2, April-2014, ISSN No.: 2250-0758 Page Number: 228-231

4. www.marketwatch.com/press-release/traditional-grocery-retailers-in-india-industry-facts-figurescovering-size-share-growth-and-analytical-insights-2019-12-27. 